\title{
Treating Congenital Diaphragmatic Hernia with ECMO: First Successful Case in Romania
}

\author{
Alina Elena GAIDUCHEVICl', Carmina GEORGESCU', Carmen Mariana HERISEANU', Ana Mihaela \\ BIZUBAC ${ }^{1}$, Cristina FILIP², Irina MARGARINT ${ }^{3}$, Ion CERNEA ${ }^{4}$, Catalin Gabriel CIRSTOVEANU ${ }^{1,5}$
}

\begin{abstract}
We present the first successful case of extracorporeal membrane oxygenation (ECMO) at "M.S. Curie" Emergency Clinical Hospital for Children, Newborn Intensive Care Unit: a term neonate with cardiorespiratory failure secondary to left sided congenital diaphragmatic hernia. The patient was placed on veno-venous ECMO at three days of life; however, on the fourth day, due to unstable right ventricular function, conversion to veno-arterial ECMO was mandatory. At one week of life, the patient was operated on-site for diaphragmatic hernia without ECMO support and then reintroduced on ECMO immediately after the surgical procedure, being on ECMO support for a total of 8 days. Antithrombotic treatment was administered for significant occlusion of the right common carotid artery and right internal jugular vein (complication of the cannulation for ECMO) and also long term treatment for Persistent Pulmonary Hypertension was needed. The patient was discharged at the age of four months with moderate neurodevelopmental delay. The literature review indicates that neonatal ECMO procedure in Romania is still in its early stages. Despite this state, our current case proves that ECMO can be successfully performed with increased chances of survival for neonates with severe prognosis after failure of conventional therapy.
\end{abstract}

Keywords: congenital diaphragmatic hernia, extracorporeal membrane oxygenation, persistent pulmonary hypertension, neonatology, pediatric surgery.

\section{Rezumat}

Prezentăm primul caz al unui nou-născut tratat cu succes cu ajutorul oxigenării prin membrană extracorporeală (ECMO) în secția de Terapie Intensivă Neonatală a Spitalului Clinic de Urgență pentru Copii „M. S. Curie”: un nounăscut la termen, cu insuficiență cardio-respiratorie secundară herniei diafragmatice stângi. Pacientul a necesitat la trei zile de viață suport ECMO inițial veno-venos, ulterior, în ziua următoare, în contextul insuficienței ventriculare drepte, suport ECMO veno-arterial. La o săptămână de viață s-a intervenit chirurgical la patul bolnavului. Oxigenarea prin membrană extracorporeală a fost întreruptă pe parcursul curei chirurgicale a herniei diafragmatice, și reinițiată postoperator. Oprirea suportului ECMO a fost posibilă după un total de 8 zile. S-a administrat tratament antitrombotic pentru ocluzie semnificativă a arterei carotide comune drepte și a venei jugulare interne drepte (complicații ale canulării vasculare pentru ECMO), în asociere cu tratamentul hipertensiunii pulmonare persistente. Pacientul s-a

\footnotetext{
${ }^{1}$ Neonatal Intensive Care Unit, „M.S. Curie” Emergency Clinical Hospital for Children, Bucharest, Romania

${ }^{2}$ Department of Pediatric Cardiology, „M.S. Curie" Emergency Clinical Hospital for Children, Bucharest, Romania

${ }^{3}$ Department of Cardiac Surgery, "M.S. Curie" Emergency Clinical Hospital for Children, Bucharest, Romania

${ }^{4}$ Department of Pediatric Surgery, „M.S. Curie" Emergency

Clinical Hospital for Children, Bucharest, Romania

${ }^{5}$ "Carol Davila" University of Medicine and Pharmacy, Bucharest, Romania
}

\section{Corresponding author.}

Catalin Gabriel CIRSTOVEANU, Neonatal Intensive Care

Unit, „M.S. Curie” Emergency Clinical Hospital for Children, 20 Constantin Brancoveanu Boulevard, Zip Code 041451, Bucharest, Romania.

E-mail: cirstoveanu@yahoo.com 
externat la vârsta de patru luni cu dezvoltare neuropsihomotorie moderat întârziată. Analiza literaturii de specialitate demonstrează că în România utilizarea ECMO la nou-născuți este încă la început. Cu toate acestea, cazul de față demonstrează că ECMO poate fi realizat cu success și oferă șanse crescute de supraviețuire nou-născuților cu prognostic sever după eșecul terapiei convenționale.

Cuvinte cheie: hernie diafragmatică congenitală, extracorporeal membrane oxygenation, hipertensiune pulmonară persistentă, neonatologie, chirurgie pediatrică.

\section{INTRODUCTION}

Congenital diaphragmatic hernia $(\mathrm{CDH})$ is a developmental defect of the diaphragm that allows abdominal viscera to herniate into the chest cavity. According to the European Surveillance of Congenital Anomalies, the reported incidence of CDH in 2018 for all pregnancies from 20 weeks onwards was 2.58 per 10.000 and 1.93 per 10.000 for live-born infants ${ }^{1}$. CDH remains a challenging condition, despite the progress of antenatal diagnosis and improvements in neonatal care. Multiple factors such as prematurity, associated abnormalities, severity of persistent pulmonary hypertension, type of repair and need for extracorporeal membrane oxygenation affect the survival. Progresses made in the management of $\mathrm{CDH}$ led to an improvement in the overall survival rate of up to $70-90 \%$ in non-ECMO infants ${ }^{2}$ and up to $48.7 \%$ for infants undergoing $\mathrm{ECMO}^{3}$. In the first hours of life, neonates with $\mathrm{CDH}$ typically present symptoms related to respiratory distress ranging from mild to severe, up to incompatible with life. Clinical manifestations of $\mathrm{CDH}$ result from the pathologic effects of the herniated viscera on lung development, in particular due to lung hypoplasia and abnormal development of the pulmonary vasculature, leading to persistent pulmonary hypertension of the newborn ${ }^{4}$.

The current practice prior to surgery includes mild ventilation from birth, hemodynamic support and treatment of pulmonary hypertension. In case conventional treatment is insufficient, ECMO is the next intervention considered, if available. ECMO is an indispensable procedure for cases of neonates with severe cardiorespiratory failure that does not respond to conventional treatment as it improves oxygenation and organ perfusion. Since the first case of successful neonatal ECMO for a severe respiratory failure in $1975^{5,6}, \mathrm{ECMO}$ has been used and saved thousands of neonates suffering from respiratory and/or cardiac failure worldwide. The most common candidate diseases for neonatal ECMO are meconium aspiration syndrome, persistent pulmonary hypertension of the neonate, $\mathrm{CDH}$ and severe sepsis ${ }^{3}$. $\mathrm{CDH}$ is currently the most common indication for $\mathrm{ECMO}$ in neonates ${ }^{4}$. Case series from ECMO centers offer convincing evidence of its potential to save severely ill patients.

Neonatal ECMO is still at an early stage in Romania, in comparison with other countries. The current paper presents the first neonate with $\mathrm{CDH}$ for whom ECMO procedure led to a positive outcome.

\section{CASE PRESENTATION}

A term male neonate was born at 39 weeks of gestation by spontaneous vaginal delivery at a regional hospital, from an uninvestigated high-risk pregnancy (nuchal cord, chorioamnionitis). The birth weight was 3130 grams and the Apgar score was 7, 3 and 4 at 1, 5 and 10 minutes, respectively. In the first hours of life the patient was intubated due to respiratory distress and a chest X-ray confirmed the $\mathrm{CDH}$ diagnosis.

The patient was admitted in our unit on the second day of life, with severe general status and high-frequency oscillatory ventilation (HFOV) was initiated (mean airway pressure of $15 \mathrm{cmH} 2 \mathrm{O}$, amplitude of 36 $\mathrm{cmH} 2 \mathrm{O}$, and $\mathrm{FiO} 2$ of 0.6-1), maintaining $\mathrm{SpO} 2$ of 90-95\%. The chest X-ray showed opacification of the left hemithorax with small transparent areas and the mediastinum shifted to the right. The bedside echocardiography revealed pulmonary hypertension (estimated by tricuspid regurgitation, dilation of the right ventricle, right-to-left shunt through the ductus arteriosus, $\mathrm{D}$-shaped left ventricle), moderate systolic dysfunction, atrial septal defect (ASD) and patent ductus arteriosus (PDA). Inhaled Nitric Oxide (15ppm) for the pulmonary hypertension was immediately started and inotropic and vasoactive agents (Dopamine, 
Epinephrine, Norepinephrine, Milrinone) and diuretics were administered.

In the next hours after admission, the evolution was unfavorable with respiratory acidosis and the oxygenation index increasing from 36 to 46 in just a few hours. After ruling out neonatal ECMO contraindications of intracranial hemorrhage and unrepairable congenital heart defects, a 8 Fr bicaval dual-lumen cannulation of the right jugular vein was performed percutaneously under real-time transthoracic ultrasound control (Figure 1). Subsequently, the veno-venous (VV) ECMO was initiated with a target blood flow of $120 \mathrm{ml} / \mathrm{kg} / \mathrm{min}$. An immediate result was observed; the arterial pressure improved and the inhaled Nitric Oxide (iNO) dose was decreased. The activated clotting time was maintained between 180 and 200 seconds.
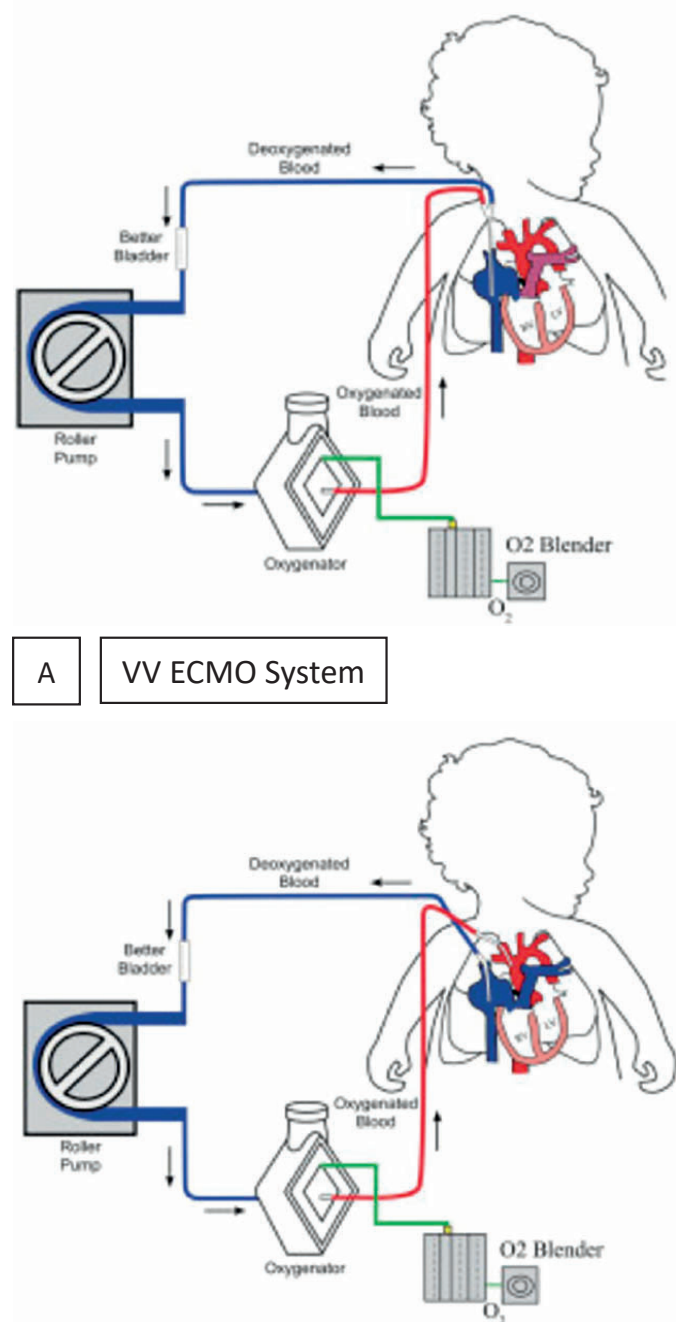

A VA ECMO System

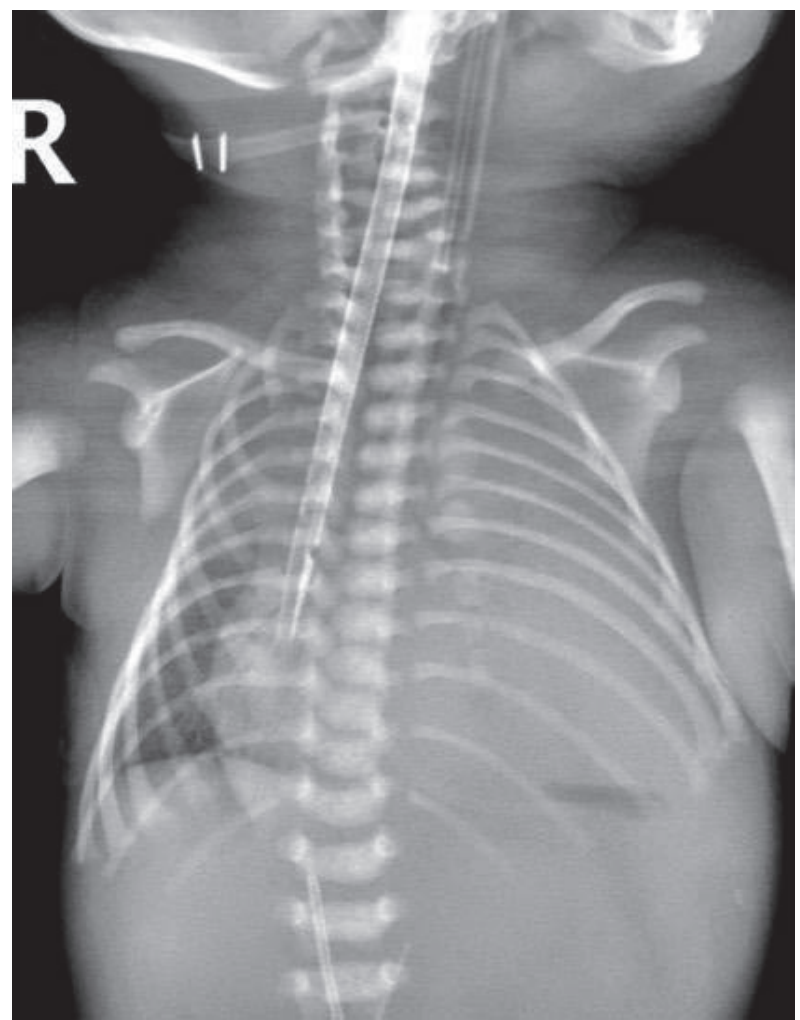

A. and B. Schematically presentation of the Veno-venous ECMO and veno-arterial ECMO

(source: www.nuemblog.com/blog/pediatric-ecmo)

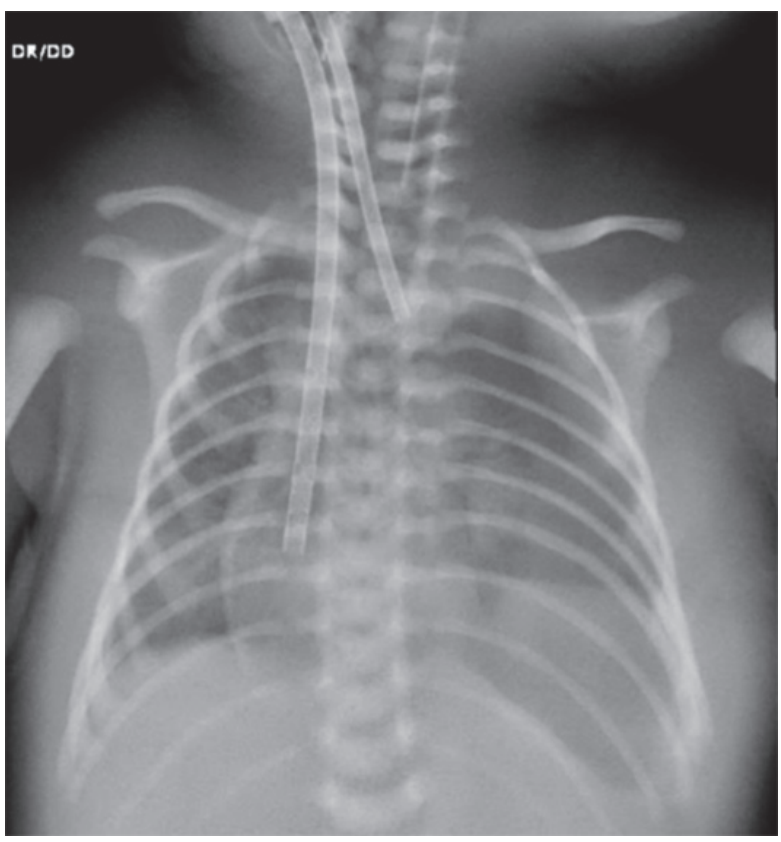

C. and D. Chest X-ray during VV and VA ECMO procedure

Figure 1. ECMO procedure principles and patients chest X-ray 
On the next day of VV ECMO, due to the biventricular dysfunction and hypoxemia, the patient was changed to a VA ECMO, with a target blood flow of $100 \mathrm{ml} / \mathrm{kg} / \mathrm{min}$ (Figure 2). The VA ECMO cannulation was achieved by sternotomy and direct surgical cannulation of the right atrium (via the right jugular vein) and aorta (via the common carotid artery). This strategy proved effective in providing adequate oxygenation $\left(\mathrm{SpO}_{2} 95 \%\right)$ and $\mathrm{CO}_{2}$ removal, allowing the decrease of the inotropic support. During ECMO, the HFOV was set to minimize ventilator induced lung injury while ensuring adequate lung recruitment.

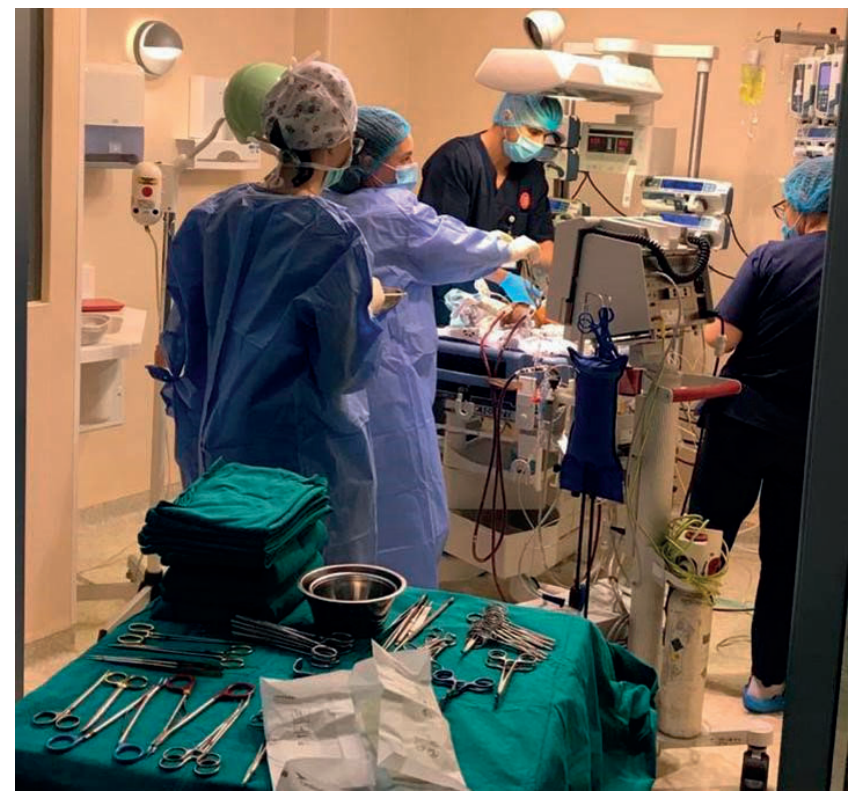

A: Transferring from VV to VA ECMO

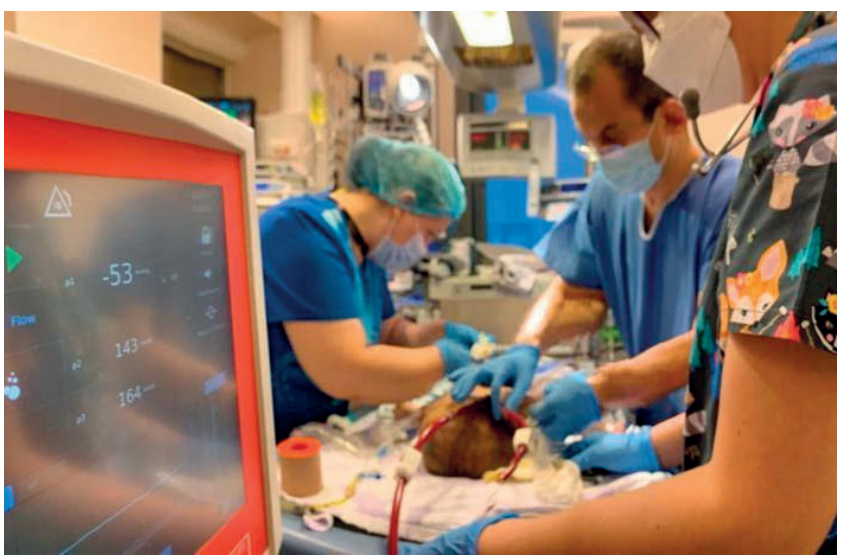

B: VA ECMO, the initiation of the procedure

Figure 2. Pictures of the ECMO procedure
On postnatal day 7 (5 days of ECMO running) a multidisciplinary team of pediatric surgeons, neonatologists and anesthesiologists, decided to have the surgical repair of the diaphragmatic hernia in the NICU due to the hemodynamic instability and the need to administer inhaled Nitric Oxide. The patient was weaned off ECMO, changed to conventional mechanical ventilation, and continued to receive iNO and cardiovascular medical support. Surgical treatment of the left-sided diaphragmatic hernia was performed via laparotomy, with the reintroduction into the peritoneal cavity of the intrathoracic herniated organs (spleen, ileal and jejunal loops, segments of colon) and the closure of the diaphragmatic defect with non-absorbable threads. There were no unforeseen events and no complications during the surgery. Immediately after the procedure, due to deteriorating condition, the patient was reintroduced on VA ECMO, maintained for more days, and thereafter safely decannulated.

During the 8 days of ECMO support, the blood gas, lactate level, and glucose level were monitored every 6 hours. The ECMO procedure was well tolerated, without major complications. However, the post-surgical cardiac and vascular ultrasound showed significant occlusion of the right common carotid artery (vertebral artery with increased caliber and flow), and right internal jugular vein occlusion (reduced venous collateral circulation). Heparin treatment was initiated for thrombosis, as well as Prostacycline (used also for the treatment of PPHT, along Sildenafil). By the time of discharge, the vascular ultrasound control exam revealed multiple compensatory collateral vascularization, with the total occlusion of the right internal carotid artery (Figure 3).

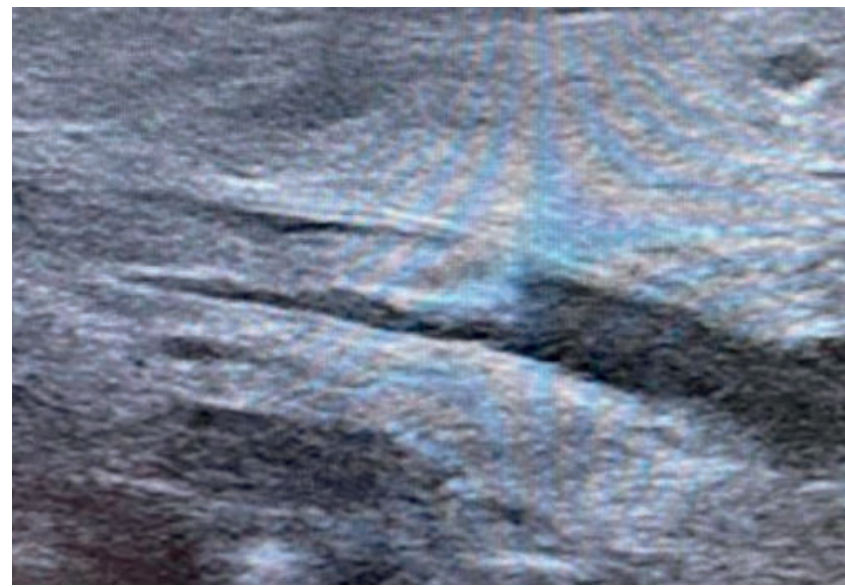

A. Occlusion of the right internal carotid artery by an intraluminal extensive thrombus 


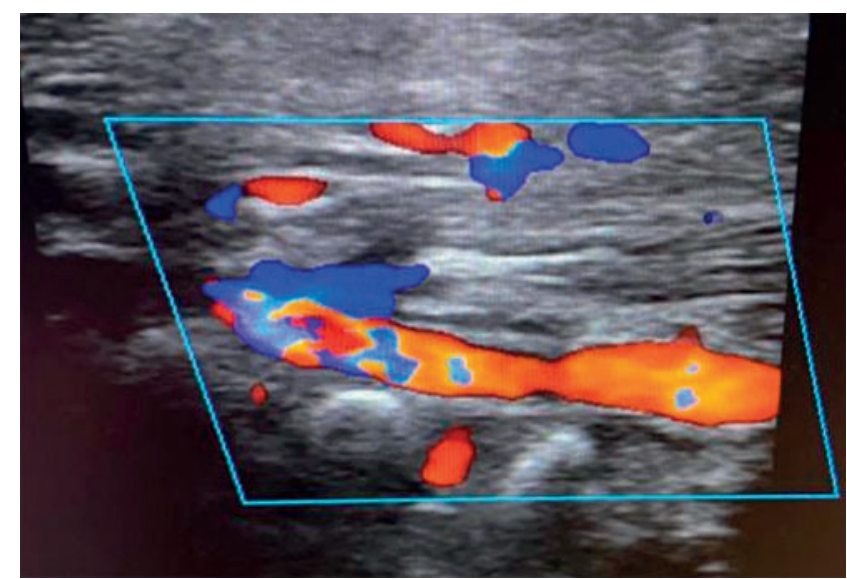

B. Discontinuity of the color Doppler image due to the presence of an thrombus in the right internal carotid

Figure 3. Ultrasound image of the vascular occlusion

Neurologic evaluations through serial transfontanelar ultrasounds revealed moderate diffuse cerebral atrophy and mild biventricular ventriculomegaly. At one and a half months of age, Phenobarbital was administered for paroxysmal manifestations (opisthotonus, extreme agitation), with favorable response.

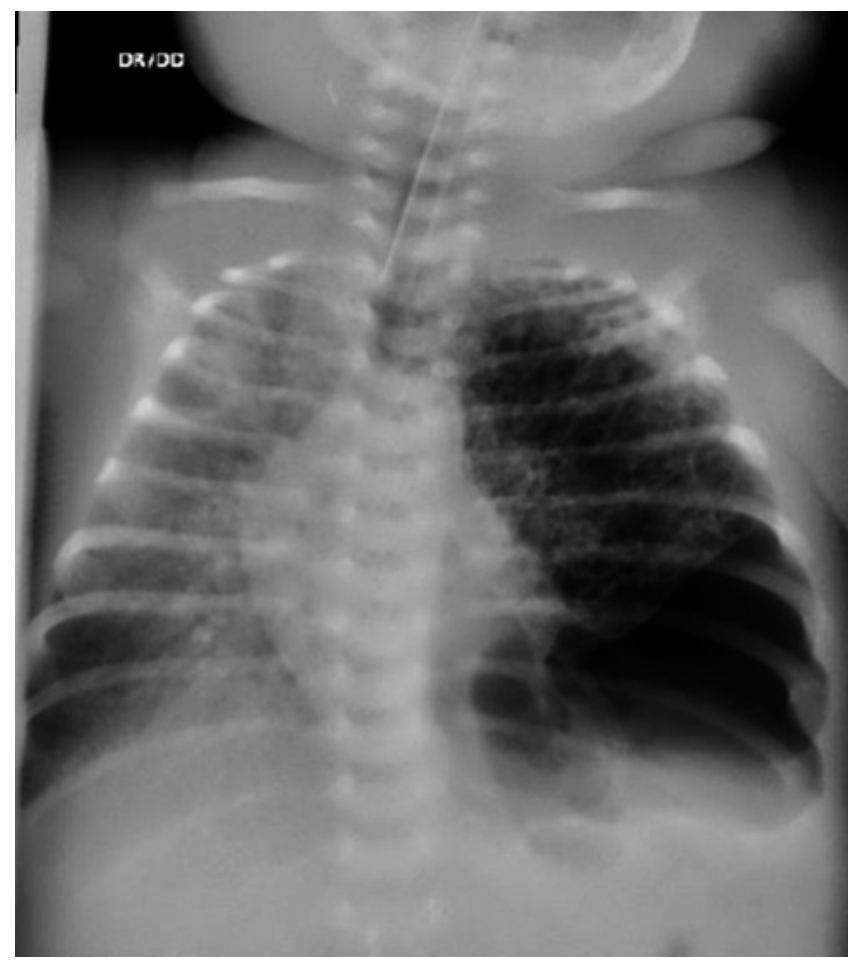

A. Postdecanulation, masiv residual pneumothorax and pulmonary hypoplasia of the left lung

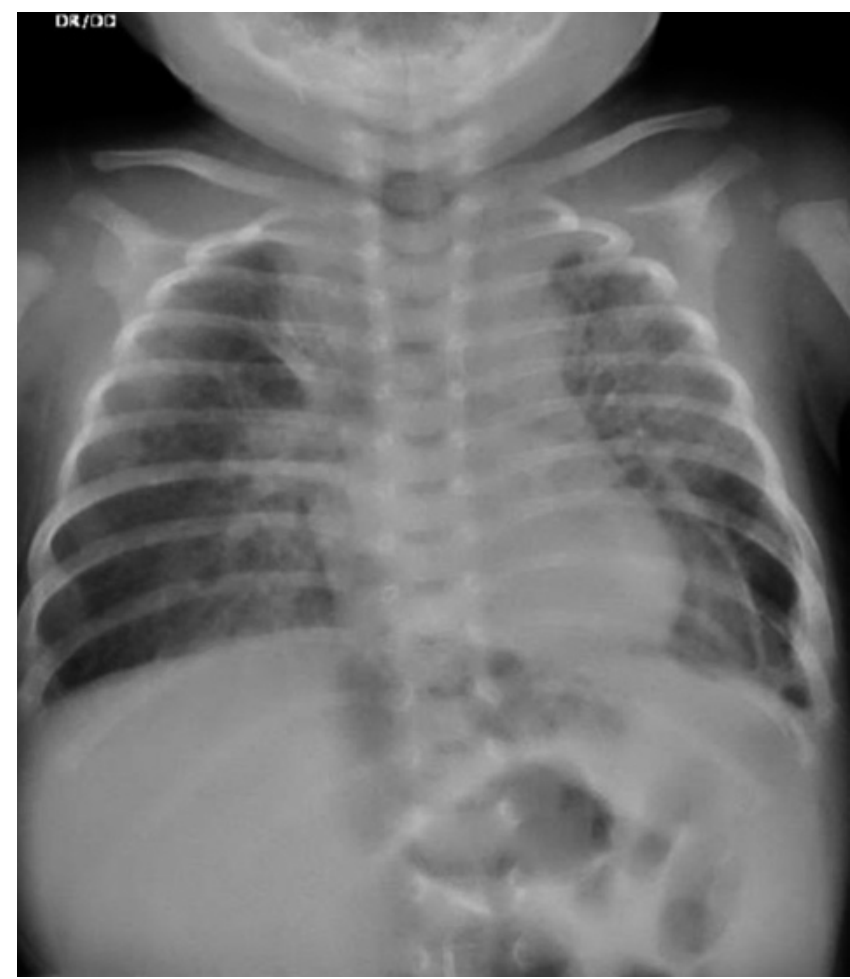

B. Before discharge, complete lung expansions

Figure 4. Post surgery chest X-ray in dynamics

The patient was on mechanical ventilation (invasive and non-invasive) with $\mathrm{O}_{2}$ requirements for a prolonged period of time, due to pulmonary hypoplasia and Bronchopulmonary Dysplasia (BPD) (Figure 4). At four months of age the patient was discharged at home, with no echocardiographic evidence of PPHT.

\section{DISCUSSIONS}

Congenital diaphragmatic hernia is one of the most severe neonatal malformations, with high mortality rates worldwide, and is currently the most common indication for extracorporeal membrane oxygenation (ECMO) in neonates ${ }^{4}$.

The diaphragmatic defect forms during the embryonic phase of lung development, leading to markedly decreased branching of the bronchioles, thickening of the alveolar septa, and decrease of the respiratory acinus and alveolar volume ${ }^{10}$. The total pulmonary vascular bed is reduced, with decreased vascularization per unit of lung. In addition, pulmonary vasculature is remodeled with thickening of the small pulmonary arteries and arterioles. Pulmonary hypertension can arise even in minor lung hypoplasia, causing right-to-left shunt, 
persistent fetal circulation, and exacerbating hypoxemia and hypercarbia ${ }^{19}$.

Antenatal ultrasound screening is routinely performed in most developed countries and identifies $>70 \%$ of cases of $\mathrm{CDH}^{13}$. Lung-to-head ratio is often used along with liver herniation to predict survival and short-term morbidity. Liver herniation seems to be highly predictive of ECMO (80\% - liver-up vs. $25 \%$ - liver-down) and survival (45\% - liver-up vs. 93\% liver-down $)^{14}$.

A first feature of the case presented is the absence of the antenatal diagnostic. This led to the lack of application of the standardized protocols considered essential for the patient outcome (intubation at birth, gentle ventilation, and aggressive treatment of pulmonary hypertension $)^{15}$. Also, the need of transferring infants with $\mathrm{CDH}$ is known to be associated with worse survival compared with infants who are born at a tertiary center ${ }^{28}$.

Besides the most used investigation, chest $\mathrm{X}-\mathrm{ray}^{8}$, the echocardiography is conducted to detect any associated cardiac anomalies, to evaluate the presence and severity of pulmonary hypertension, and to assess ventricular function. These factors influence prognosis and management decisions.

For our patient, cardiac ultrasound revealed that despite the severe pulmonary hypertension, considered as a significant predictor and cause of morbidity and mortality in $\mathrm{CDH}^{11,12}$, the cardiac function was satisfactory by the time of the admission and in the next hours. This fact played an important role in choosing the veno-venous type of ECMO initially applied.

Due to the continually unfavorable evolution, although on HFOV and iNO, simultaneously administration of Dopamine, Epinephrine, Milrinone and Norepinephrine was necessary to sustain a blood pressure value at an accepted limit for the gestational age. The Vasoactive-Inotropic Score (VIS) that quantifies the amount of cardiovascular support required by patient, revealed a VIS 40 on the day of admission, which put him at high risk for cardiac arrest, death, or need for $\mathrm{ECMO}^{9}$.

Admitting that identifying patients requiring ECMO remains a challenge, our patient met the criteria suggested by Extracorporeal Life Support Organization (ELSO) and the CDH EURO Consortium Consensus - 2015 Update $^{4,15}$ to initiate ECMO. As recommended, the significant modified parameters as hypoxia $(\mathrm{SpO} 2$ $80-85 \%$ preductal), respiratory acidosis despite proper ventilation, need for high mean airway pressure (15-17 $\mathrm{cm} \mathrm{H}_{2} \mathrm{O}$ ) to maintain $\mathrm{SpO}_{2}>85 \%$, tendency to hypotension unresponsive to i.v. fluid and inotropic support, and the most important, Oxygenation index $>40$ to a maximum of 46 for more than 3 hours, led to the decision of initiating veno-venous ECMO.

Although both veno-venous (VV) and veno-arterial types of ECMO may be used to support infants with $\mathrm{CDH}$ with equivalent survival rate reports ${ }^{19,16}$, the decision of initiating VV versus VA was based on specific clinical evidence (satisfactory left ventricle function), our center experience (four other cases on VV ECMO) and the availability to cannulate percutaneously the right internal jugular vein ${ }^{17}$.

Despite the fact that the prognosis worsens when converting from VV to VA ECMO ${ }^{16}$, this was mandatory due to cardiac failure. VA ECMO has an advantage in infants with cardiac dysfunction (unloading the right ventricle and maintaining good systemic output $)^{19}$.

Weaning off ECMO after the optimization of fluid and cardiorespiratory support, in order to perform the surgical repair of the $\mathrm{CDH}$, the so-called "post decannulation repair" is the main recommended practice ${ }^{22-24}$. For our patient „The 2015 updated consensus” 15 criteria for the pre-operative stabilization were met, and the standard surgical approach to repair the diaphragmatic defect was applied. The surgery was performed on site due to pulmonary and hemodynamically unstable status.

ECMO was required for a total of 8 days, while typically, the duration of ECMO support in $\mathrm{CDH}$ patients is between 1 and 4 weeks ${ }^{2,19}$. The survival rates, reported in the literature, based on the duration of ECMO run are $56 \%$ for 2 weeks, $46 \%$ for 3 weeks, $43 \%$ for 4 weeks; afterwards the survival declines to $15 \%$. The need for a second ECMO support, in our case after the surgery repair, decreases the chances of survival to $44 \%{ }^{20}$.

Mortality can be reliably predicted with validated clinical variables summed up in the pre- and on-ECMO mortality-risk models for congenital diaphragmatic hernia ${ }^{18}$. These risk models ${ }^{21}$ take into account the possible contributions of anatomic variations of $\mathrm{CDH}$, pre-ECMO rescue therapies, timing of surgical repair, comorbidities, length of ECMO stay and complications. The pre-ECMO mortality risk of our patient was $66.20 \%$ (95\% confidence interval: 52.57 - 79.83\%), while the on-ECMO, after surgery, mortality risk declined to $29.44 \%$ ( $95 \%$ confidence interval: 22.42 - 36.46\%), proving the appropriate and timely use of ECMO (Figure 5). 

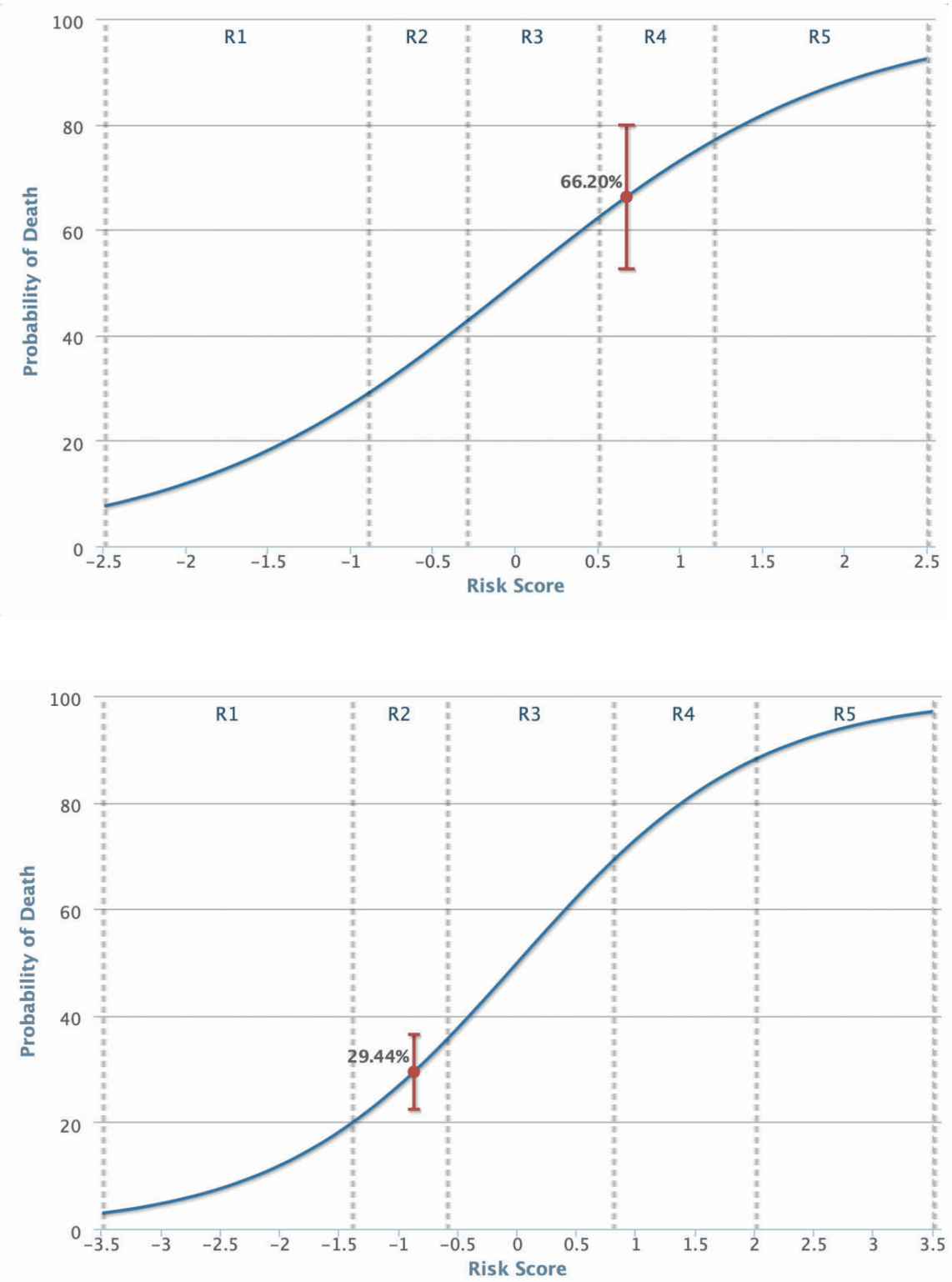

A. Pre ECMO probability of mortality: $66.2 \%$. Risk group 4

B. On ECMO probability of mortality: $29.4 \%$.

Risk group 2

Figure 5. Pre and on ECMO mortality-risk model for congenital diaphragmatic hernia (source: www.choc.org/ecmocalc).
In terms of long term outcome, post ECMO neurological deficits have been reported in $10-30 \%$ of patients ${ }^{27}$, correlated to persistent hypoxemia and to loss of autoregulation of cerebral blood flow. Lung and vascular developmental abnormalities are the primary causes of morbidity and mortality in infants with $\mathrm{CDH}$. Survivors, especially those treated with ECMO, are at risk for respiratory infections and chronic lung disease ${ }^{25}$. Oxygen dependency, as in the case we presented, is common, $50 \%$ of patients being oxygen dependent at 28 days of age, $16 \%$ at the time of discharge for a mean duration of 14 months and $2 \%$ remaining oxygen dependent at 2 years of age $\mathrm{e}^{26}$.
Analysis of ECMO in pediatric patients demonstrated a volume-outcome relationship with decreased mortality at institutions performing at least $30 \mathrm{ECMO}$ cases per year ${ }^{29}$. High-volume centers are associated with greater experience through practice. Low-volume ECMO centers may benefit from more flexible case selection criteria, as to perform ECMO in cases with lower prognosis, as a way of increasing center volume and gaining experience ${ }^{30}$. Our clinic experience registered in the last 5 years 10 cases ECMO support in our Neonatal Intensive Care Unit, four of them having been cases of $\mathrm{CDH}$. 


\section{CONCLUSIONS}

$\mathrm{CDH}$ remains a challenging medical condition that requires difficult and involved procedures to achieve a positive outcome.

Although the use of ECMO in $\mathrm{CDH}$ remains controversial, our experience indicates that, when available, ECMO could be considered for almost all infants who cannot be treated with conventional medical therapy.

The most adequate surgery time for the patients on ECMO must be wisely chosen taking into account the latest protocols. Based on our experience the on-side surgery is a safe procedure leading to improved outcomes and therefore could also be considered.

\section{References}

1. https://eu-rd-platform.jrc.ec.europa.eu/eurocat/eurocat-data/ prevalence_en

2. Seetharamaiah R, Younger JG, Bartlett RH, Hirschl RB, Congenital Diaphragmatic Hernia Study G. Factors associated with survival in infants with congenital diaphragmatic hernia requiring extracorporeal membrane oxygenation: a report from the congenital diaphragmatic hernia study group. Journal of Pediatric Surgery. 2009;44(7):1315-21

3. Turek, Joseph W et al.; Shifting Risks and Conflicting OutcomesECMO for Neonates with Congenital Diaphragmatic Hernia in the Modern Era. The Journal of Pediatrics vol. 190 (2017): 163168.e4. doi:10.1016/j.jpeds.2017.08.010

4. Brogan T V., Lequier L, Lorusso R, MacLaren G, Peek G, editors. Congenital diaphragmatic hernia and ECMO. Extracorporeal Life Support: The ELSO Red Book 5th Edition. Ann Arbor, MI: ELSO (2017). p. 137-43.

5. Bartlett RH, Gazzaniga AB, Huxtable RF, Schippers HC, O'Connor MJ, Jefferies MR. Extracorporeal circulation (ECMO) in neonatal respiratory failure. Journal of Thoracic and Cardiovascular Surgery. 1977 Dec;74(6):826-33. PMID: 926812.

6. Bartlett RH. Esperanza: The First Neonatal ECMO Patient. ASAIO J. 2017 Nov/Dec;63(6):832-843. doi: 10.1097/ MAT.0000000000000697. PMID: 29084039.

7. Chukwulebe S, Lang S. (2019, April 8). Pediatric ECMO: Beyond the basics of pediatric resuscitation [NUEM Blog. Expert Commentary by Harris L \& Allen K]. Retrieved from http://www. nuemblog.com/blog/pediatric-ecmo

8. Holly L Hedrick, MDN Scott Adzick, MD. Congenital diaphragmatic hernia in the neonate. In: UpToDate, Post TW (Ed), UpToDate, Waltham, MA. (Accessed on May 04, 2021)

9. [9] McIntosh AM, Tong S, Deakyne SJ, Davidson JA, Scott HF. Validation of the Vasoactive-Inotropic Score in Pediatric Sepsis. Pediatr Crit Care Med. 2017;18(8):750-757. doi:10.1097/ PCC. 0000000000001191
Based on the presented data and our experience with $\mathrm{CDH}$ care, we feel confident that ECMO could improve survival chances in the most severe $\mathrm{CDH}$ compared to currently available non-ECMO techniques.

Compliance with ethics requirements: The authors declare no conflict of interest regarding this article. The authors declare that all the procedures and experiments of this study respect the ethical standards in the Helsinki Declaration of 1975, as revised in 2008(5), as well as the national law. Informed consent was obtained from all the patients included in the study.

10. Kitagawa M, Hislop A, Boyden EA, et al. Lung hypoplasia in congenital diaphragmatic hernia. A quantitative study of airway, artery and alveolar development. British Journal of Surgery 1971; 58: 342-346.

11. Wynn J, Krishnan U, Aspelund G, Zhang Y, Duong J, Stolar $\mathrm{CJH}$, et al. Outcomes of congenital diaphragmatic hernia in the modern era of management. Journal of Pediatrics (2013) 163:114-9.e1. doi: 10.1016/j.jpeds.2012.12.036

12. Mohseni-Bod H, Bohn D. Pulmonary hypertension in congenital diaphragmatic hernia. Seminars in Pediatric Surgery 2007; 16: 126-133.

13. Garne E, Haeusler M, Barisic I, et al. 2002. Congenital diaphragmatic hernia: evaluation of prenatal diagnosis in 20 European regions. Ultrasound in Obstetrics and Gynecology 2002; 19: 329-333.

14. Hedrick HL, Danzer E, Merchant A, Bebbington MW, Zhao $\mathrm{H}_{\text {, }}$ Flake AW, Johnson MP, Liechty KW, Howell LJ, Wilson RD, et al. Liver position and lung-to-head ratio for prediction of extracorporeal membrane oxygenation and survival in isolated left congenital diaphragmatic hernia. American Journal of Obstetrics and Gynecology. 2007;197(4):422 e421-424.

15. Snoek KG, Reiss IK, Greenough A, Capolupo I, Urlesberger B, Wessel L, Storme L, Deprest J, Schaible T, van Heijst A, Tibboel D; $\mathrm{CDH}$ EURO Consortium. Standardized Postnatal Management of Infants with Congenital Diaphragmatic Hernia in Europe: The CDHEURO Consortium Consensus - 2015 Update. Neonatology. 2016;110(1):66-74. doi: 10.1159/000444210. Epub 2016 Apr 15. PMID: 27077664.

16. Guner YS, Harting MT, Fairbairn K, Delaplain PT, Zhang L, Chen $\mathrm{Y}$, Kabeer MH, Yu P, Cleary JP, Stein JE, Stolar C, Nguyen DV. Outcomes of infants with congenital diaphragmatic hernia treated with venovenous versus venoarterial extracorporeal membrane oxygenation: A propensity score approach. $\mathbf{J}$ Pediatr Surg. 2018 Nov;53(11):2092-2099. doi: 10.1016/j.jpe- 
dsurg.2018.06.003. Epub 2018 Jun 7. PMID: 30318280; PMCID: PMC6192269.

17. Guner Y, Jancelewicz T, Di Nardo M, Yu P, Brindle M, Vogel AM, Gowda SH, Grover TR, Johnston L, Mahmood B, Gray B, Chapman R, Keene S, Rintoul N, Cleary J, Ashrafi AH, Harting MT; Elso $\mathrm{CDH}$ Interest Group. Management of Congenital Diaphragmatic Hernia Treated With Extracorporeal Life Support: Interim Guidelines Consensus Statement From the Extracorporeal Life Support Organization. ASAIO J. 2021 Feb 1;67(2):113-120. doi: 10.1097/MAT.0000000000001338. PMID: 33512912.

18. Guner YS, Nguyen DV, Zhang L, Chen Y, Harting MT, Rycus $P$, Barbaro R, Di Nardo M, Brogan TV, Cleary JP, Yu PT. Development and Validation of Extracorporeal Membrane Oxygenation Mortality-Risk Models for Congenital Diaphragmatic Hernia. ASAIO J. 2018 Nov/Dec;64(6):785-794. doi: 10.1097/ MAT.0000000000000716. PMID: 29117038; PMCID: PMC5938163.

19. Rafat, Neysan, and Thomas Schaible. "Extracorporeal Membrane Oxygenation in Congenital Diaphragmatic Hernia." Frontiers in pediatrics vol. 7 336. 8 Aug. 2019, doi:10.3389/ fped.2019.00336

20. Kays, David W et al. "Extracorporeal life support in patients with congenital diaphragmatic hernia: how long should we treat?." Journal of the American College of Surgeons vol. 218,4 (2014): 808-17. doi:10.1016/j.jamcollsurg.2013.12.04

21. www.choc.org/ecmocalc

22. Keijzer R, Wilschut DE, Houmes RJ, van de Ven KP, van den Hout L, Sluijter I et al. Congenital diaphragmatic hernia: to repair on or off extracorporeal membrane oxygenation? Journal of Pediatric Surgery 2012;47:631-6.

23. Partridge EA, Peranteau WH, Rintoul NE, Herkert LM , Flake AW, Adzick NS et al. Timing of repair of congenital diaphragmatic hernia in patients supported by extracorporeal membrane oxygenation (ECMO). Journal of Pediatric Surgery 2015;50:260-2.
24. Delaplain PT , Harting MT, Jancelewicz T , Zhang L , Yu PT , Di Nardo $M$ et al. Potential survival benefit with repair of congenital diaphragmatic hernia $(C D H)$ after extracorporeal membrane oxygenation (ECMO) in select patients: study by ELSO CDH Interest Group. Journal of Pediatric Surgery 2019;54:1132-7.

25. Dao DT, Hayden LP, Buchmiller TL, et al. Longitudinal Analysis of Pulmonary Function in Survivors of Congenital Diaphragmatic Hernia. Journal of Pediatrics 2020; 216:158.

26. Jaillard SM, Pierrat V, Dubois A, et al. Outcome at 2 years of infants with congenital diaphragmatic hernia: a population-based study. Annals of Thoracic Surgery 2003; 75: 250-256.

27. Peetsold, M.G., Heij, H.A., Kneepkens, C.M.F. et al. The long-term follow-up of patients with a congenital diaphragmatic hernia: a broad spectrum of morbidity. Pediatric Surgery International $25,1-17$ (2009).

28. Nasr A, Langer JC, Canadian Pediatric Surgery Network. Influence of location of delivery on outcome in neonates with congenital diaphragmatic hernia. Journal of Pediatric Surgery $2011 ; 46: 814$.

29. Karamlou T, Vafaeezadeh M, Parrish AM, et al. Increased extracorporeal membrane oxygenation center case volume is associated with improved extracorporeal membrane oxygenation survival among pediatric patients. Journal ofThoracic and Cardiovascular Surgery 2013;145:470-5.

30. Barbaro RP, Odetola FO, Kidwell KM, et al. Association of hospital-level volume of extracorporeal membrane oxygenation cases and mortality. Analysis of the extracorporeal life support organization registry. Am J Respir Crit Care Med. 2015;191(8):894- 901. 